\title{
Developments in the Field
}

\section{The Swiss Human Rights Due Diligence Legislation: Between Law and Politics}

\author{
Nicolas BUENO $\mathbb{T}^{*}$ (i) and Christine KAUFMANN**
}

Keywords: child labour, conflict minerals, legal liability, mandatory human rights due diligence, Switzerland

\section{INTRODUCTION}

On 29 November 2020, Swiss citizens voted on a popular constitutional initiative, known as the Swiss Responsible Business Initiative. ${ }^{1}$ The vote was triggered by an initiative signed by more than the required 100,000 Swiss citizens who used their constitutional right to ask for an amendment of the Swiss Constitution by introducing a new provision on mandatory human rights due diligence and corporate liability. For such an initiative to be successful, both the majority of the people as well as of the cantons (states) is required. While 50.7 per cent of the participating voters accepted the initiative, the proposal did not reach the majority of the cantons and therefore the Responsible Business Initiative was rejected. Its rejection nevertheless triggered the adoption of new reporting and due diligence obligations relating to conflict minerals and child labour, which the Parliament had promised to adopt in case the Responsible Business Initiative was

II Conflicts of interest: Nicolas Bueno has provided legal advice to the Swiss Responsible Business Initiative Committee. Christine Kaufmann declares no conflicts of interest.

* Professor Nicolas Bueno (corresponding author), Swiss Distance University, Faculty of Law, Überlandstrasse 12, 3900 Brig, Switzerland. Email: Nicolas.Bueno@unidistance.ch

** Professor Christine Kaufmann, University of Zurich, Center for Human Rights Studies, Rämistrasse 74, 8001 Zürich, Switzerland. Email: Christine.Kaufmann@uzh.ch

1 Swiss Federal Chancellery, 'Initiative populaire fédérale "Entreprises responsables: pour protéger l'être humain et l'environnement"', http://www.bk.admin.ch/ch/f/pore/vi/vis462t.html (accessed 5 August 2021), for the official text in French, German and Italian. Swiss Coalition for Corporate Justice, 'The initiative text with explanations', https:// corporate-responsibility.org/wp-content/uploads/2019/10/KVI_Factsheet_5_E.pdf (accessed 5 August 2021), for a non-official English translation. 
rejected. ${ }^{2}$ This contribution outlines the content of the newly adopted human rights due diligence legislation that will reflect the due diligence standard for companies in Switzerland for the years to come. It also aims to inform policy makers in other countries by describing the political struggle underlying the adoption of mandatory human rights due diligence in Switzerland.

This piece is structured as follows. Section II analyses the new human rights due diligence legislation in the broader political context of the rejected Responsible Business Initiative. Section III then explains the content of the newly adopted conflict minerals and child labour due diligence obligations in the Swiss Code of Obligations. Section IV finally critically examines these new provisions in the emerging ecosystem of mandatory human rights due diligence.

\section{The Rejected Swiss Responsible Business Initiative}

The Swiss Responsible Business Initiative aimed at introducing a new provision on the human rights responsibility of business enterprises in the Swiss Constitution. It was launched by a coalition of civil society organizations supported by several politicians and companies in Switzerland. This constitutional provision contained two main elements: a due diligence obligation for business enterprises and a specific provision on their legal liability. ${ }^{3}$

Regarding due diligence, the Responsible Business Initiative required that companies registered in Switzerland identify impacts on human rights and the environment, take appropriate measures to prevent or cease adverse impacts, and account for how they address them. The due diligence duties covered the activities of controlled companies as well as those of all business relationships along the entire value chain. Finally, the interests of small and medium-sized enterprises (SMEs) had to be taken into account. ${ }^{4}$

With respect to legal liability, the initiative aimed at introducing a specific legal liability for the damage caused by a controlled company. ${ }^{5}$ By limiting legal liability to the damage caused by a controlled company, the proposed liability provision did not cover the full scope of the due diligence obligation. The controlling company would have been liable for this damage, but could escape liability by proving that it carried out appropriate due diligence to prevent it. ${ }^{6}$ This specific civil liability for the damage

\footnotetext{
2 Swiss Federal Office of Justice, 'Code des Obligations: Contre-projet indirect à l'initiative populaire "Entreprises responsables - pour protéger l'être humain et l'environnement"', https://www.parlament.ch/centers/eparl/curia/2016/ 20160077/Texte\%20pour\%20le\%20vote\%20final\%202\%20NS\%20F.pdf (accessed 5 August 2021), for the official text in French, German and Italian.

3 Nicolas Bueno, 'The Swiss Popular Initiative on Responsible Business: From Responsibility to Liability' in Liesbeth Enneking et al (eds.), Accountability, International Business Operations and the Law: Providing Justice for Corporate Human Rights Violations in Global Value Chains (Abingdon: Routledge, 2020) 239-259; Chiara Macchi and Claire Bright, 'Hardening Soft Law: The Implementation of the Human Rights Due Diligence Requirements in Domestic Legislations' in Martina Buscemi et al (eds.), Legal Sources in Business and Human Rights: Evolving Dynamics in International and European Law (Leiden: Brill, 2020) 218, 230.

4 Responsible Business Initiative, Proposed Art 101a al. 2 lit. b of the Swiss Constitution.

5 Responsible Business Initiative, Proposed Art 101a al. 2 lit. c of the Swiss Constitution.

6 Nicolas Bueno and Claire Bright, 'Implementing Human Rights Due Diligence through Corporate Civil Liability' (2020) 69:4 International \& Comparative Law Quarterly 789, 805.
} 
caused by a controlled company, with an exoneration clause for the controlling company, addressed the practical difficulty that plaintiffs may face in bringing evidence about the conduct of controlling companies located abroad.

The mechanism of legal liability triggered an intense parliamentary debate before the popular vote. In June 2018, one chamber of the Parliament adopted a first counterproposal that limited the scope of due diligence to large companies and made the legal liability provision expressly inapplicable to the damage caused by a supplier. ${ }^{7}$ Despite this compromise, the majority of the members of the second parliamentary chamber as well as the government argued that this first counterproposal still contained the main elements of the Initiative, particularly legal liability, and was therefore not really an alternative. While the main business associations lobbied against the first counterproposal, there were also prominent voices, including companies of all sizes as well as business associations, in favour of it. In an unusual move during these discussions, the government mandated the Federal Department of Justice and Police to elaborate an alternative approach which would not contain any legal liability and focus on child labour and conflict minerals. ${ }^{8}$ This approach was the basis for a second counterproposal. With this much lighter alternative, the second chamber of parliament finally rejected the first counterproposal. A few months before the popular vote, in June 2020, both chambers agreed to pass this much lighter version of human rights due diligence legislation in case the Responsible Business Initiative was rejected. ${ }^{9}$

\section{The New Swiss Due Diligence Legislation}

The new human rights due diligence legislation adopted as a consequence of the Responsible Business Initiative's rejection takes the form of a modification of the Swiss Code of Obligations and of the Swiss Criminal Code. ${ }^{10}$ It applies a fundamentally different approach than the Responsible Business Initiative in two regards. First, it does not impose a general due diligence obligation across all sectors and issues. It introduces general reporting obligations and specific conflict minerals and child labour due diligence obligations. Second, it does not introduce new provisions on the legal liability of companies for the harm caused by a subsidiary or a supplier. These new provisions in the Swiss Code of Obligations are expected to enter into force on 1 January 2022 together with a new Federal Ordinance on Conflict Minerals and Child Labour containing implementing provisions. ${ }^{11}$

\footnotetext{
7 Franz Werro, 'The Swiss Responsible Business Initiative and the Counter-Proposal' (2019) 10:2 Journal of European Tort Law 166, 167.

8 Swiss Federal Council, 'Schweizer Unternehmen sollen über Einhaltung der Menschenrechte und Umweltschutzstandards berichten', Swiss Federal Council (14 August 2019), https://www.bj.admin.ch/ejpd/de/home/ aktuell/news/2019/2019-08-140.html (accessed 5 August 2021), also available in French and Italian.

9 Nicolas Bueno, 'Diligence en matière de droits de l'homme et responsabilité de l'entreprise: le point en droit suisse' (2019) 29 Swiss Review of International and European Law 345, 362.

10 See note 2, for the official text.

11 Swiss Federal Ordinance on Due Diligence and Transparency on Conflict Minerals and Child Labour (Ordinance on Conflict Minerals and Child Labour).
} 


\section{A. General Non-Financial Reporting Obligations}

The law introduces new reporting requirements on environmental, social and labour-related issues as well as on human rights and measures against corruption. ${ }^{12}$ This new reporting obligation was inspired by the European Union (EU) non-financial reporting directive. ${ }^{13}$ In Switzerland, the reporting obligation applies essentially to large companies with at least 500 employees on yearly average and a minimum balance sheet turnover of CHF20 million or a minimum turnover of CHF40 million. The report has to cover the business model, identified risks, indicators for monitoring and the due diligence concepts applied by the company regarding human rights, environmental and social issues as well as corruption. ${ }^{14}$ The report has to be published and will remain public for 10 years. No report needs to be published if reasons are given in writing (comply or explain). Non-compliance with the reporting obligations can be subject to criminal sanctions up to CHF $100,000 .{ }^{15}$

\section{B. Specific Due Diligence Obligations on Conflict Minerals and Child Labour}

\section{Companies Subject to Due Diligence Obligations}

Beyond general reporting requirements, the Swiss Code of Obligations introduces new specific due diligence obligations for companies that have their registered office, central administration, or principal place of business in Switzerland in two cases. ${ }^{16}$ The due diligence obligations apply to companies importing or processing minerals or metals in Switzerland, containing tin, tantalum, tungsten or gold originating from conflict-affected and high-risk areas, above a certain threshold. They also apply to companies that sell goods or services if there are reasonable grounds to suspect that they were produced with child labour. The law also contains several exceptions that are elaborated on in the new implementing Ordinance on Conflict Minerals and Child Labour.

For conflict minerals, supply chain due diligence obligations apply only to companies importing or processing minerals above a minimum threshold similar to the EU Conflict Minerals Regulation. The import and processing of recycled metals is not subject to the due diligence and reporting obligations. ${ }^{17}$ Three important exceptions have also been introduced with respect to child labour. First, child labour supply chain due diligence does not apply to SMEs, defined as companies with less than 500 employees and a balance sheet of less than CHF20 million or a turnover of CHF40 million. Secondly, large companies are also excluded from due diligence obligations if they can show that the countries from which they supply goods and services are low-risk countries with regard to child labour. A low risk is presumed if a country is listed as 'Basic' in the UNICEF Children's Rights in the Workplace Index. Thirdly, the remaining large companies are

12 Swiss Code of Obligations, art 964a-964c.

13 EU Directive 2014/95/EU of 22 October 2014 on disclosure non-financial and diversity information by certain large undertakings and groups.

14 Swiss Code of Obligations, art $964 b$.

15 Swiss Criminal Code, art 325ter.

16 Swiss Code of Obligations, art 964j-964l.

17 Swiss Ordinance on Conflict Minerals and Child Labour, arts 2 and 3. 
obliged to conduct due diligence only if there are reasonable grounds for suspecting child labour. ${ }^{18}$ This raises the question of how well-founded suspicion, or the absence thereof, can be established without first conducting due diligence in the first place.

Finally, another exception to the due diligence obligations exists for companies already respecting certain international standards. Companies subject to conflict minerals due diligence obligations are exempted if they already implement the OECD (Organisation for Economic Co-operation and Development) Due Diligence Guidance for Responsible Supply Chains of Minerals from Conflict-Affected and High-Risk Areas or the EU Conflict Minerals Regulation. With respect to child labour, companies subject to the obligations are exempted if they already implement the ILO (International Labour Organization) Conventions No. 138 and 182 on Child Labour and either the ILO-IOE (International Organisation of Employers) Child Labour Guidance Tool for Business or the OECD Due Diligence Guidance. A company that invokes this exception has to specify the standard it refers to in its report and apply it as a whole. ${ }^{19}$ This exemption aims to reward companies already respecting and fully applying international standards by reducing their administrative burden. However, the criteria on how to assess whether a company fulfils the mentioned international standards are far from clear as they do not contain a monitoring mechanism. Therefore, as much as the reference to international standards and the quest for aligning national due diligence requirements with them is a positive and innovative step, there is still a need to further specify the criteria for monitoring corporate performance in this regard for the provisions to be effective on the ground.

\section{Content and Enforcement of Due Diligence Obligations}

Companies subject to the due diligence obligations must have a management system in place that contains four elements. The new Ordinance on Conflict Minerals and Child Labour specifies the content of each element. First, the management system requires the adoption of a supply chain policy. Among other elements, companies must communicate with the public and their suppliers about their conflict minerals and/or child labour supply chain policy and include it in contracts with suppliers. They must also allow interested individuals and organizations to provide information about risks in their supply chains. ${ }^{20}$

Second, companies must establish a traceability system in their supply chains. ${ }^{21}$ Mineral importers, for example, must indicate and document the name of the supplier, the country of origin and the volume and date of extraction of the minerals. If the minerals originate from a conflict area, additional information is required, such as the mine of origin, the locations where minerals are consolidated, traded or processed as well as all taxes or other payments made in relation to the minerals. A similar list of required information is required for metals. For products for which there are reasonable grounds to suspect that they were produced with child labour, ${ }^{22}$ the duty to establish a traceability

\footnotetext{
18 Swiss Ordinance on Conflict Minerals and Child Labour, arts 4 and 5.

19 Swiss Ordinance on Conflict Minerals and Child Labour, art 6.

20 Swiss Ordinance on Conflict Minerals and Child Labour, arts 7 and 8.

21 Swiss Ordinance on Conflict Minerals and Child Labour, arts 9 and 10.

22 See sentence related to citation 18 , above.
} 
system requires that companies describe the product and list the name and address of the supplier as well as of all production sites or service providers of all components of the product along the entire supply chain. ${ }^{23}$

Third, companies must identify and evaluate risks based on their supply chain policy and tracing system. ${ }^{24}$ Fourth, they must adopt a management plan to reduce the identified risks to the extent possible. ${ }^{25}$ The annex to the OECD Guidance on Conflict Minerals and the ILO-IOE Child Labour Guidance Tool provides further guidance on how to identify, evaluate and adopt such a management plan.

The question of enforcement of these due diligence obligations is quite lacunary in the law. Apart from an audit by independent auditing companies authorized by the government that will verify compliance with conflict minerals due diligence obligations, the only enforcement mechanism is a criminal sanction of up to CHF 100,000 for not reporting on the implementation of due diligence obligations. ${ }^{26}$ There is no further mention of how due diligence obligations should be enforced with respect to child labour. It is also unclear how the breach of these due diligence obligations may be considered as a fault and lead to a tort in civil liability proceedings. The lack of an enforcement mechanism is clearly a weakness of the newly introduced legislation in Switzerland.

\section{The Swiss Approach in International Context}

During the campaign before the popular vote on the Responsible Business Initiative, the government emphasized that the new conflict minerals and child labour due diligence obligations were aligned with the legislation of other European countries. According to the proponents of the counterproposal, Switzerland would therefore become a good example on human rights due diligence without impacting its competitiveness. The new Swiss due diligence legislation can nevertheless be criticized for at least three reasons.

To begin with, the Swiss human rights due diligence legislation comes at a time when the international debate is moving towards comprehensive due diligence requirements, covering all sectors and all impacts on human rights and the environment as illustrated by the recent discussion on mandatory due diligence legislation in the EU, the new supply chain due diligence legislation in Germany and Norway, the Duty of Vigilance Law in France and the current discussion in the Netherlands about a comprehensive due diligence approach. ${ }^{27}$ The Swiss sectoral approach is based on assumptions that are partially

\footnotetext{
23 Swiss Federal Council, 'Rapport explicatif de l'ordonnance sur les devoirs de diligence et de transparence dans les domaines des minerais et métaux provenant de zones de conflit et du travail des enfants' (2021), arts 20-22.

24 Swiss Ordinance on Conflict Minerals and Child Labour, art 11.

25 Swiss Ordinance on Conflict Minerals and Child Labour, art 12.

26 Swiss Criminal Code, art 325ter.

27 Business and Human Rights Resource Centre, 'National and regional movements for mandatory human rights and environmental due diligence in Europe', Business and Human Rights Resource Centre (22 May 2019), https:// www.business-humanrights.org/en/latest-news/national-regional-movements-for-mandatory-human-rightsenvironmental-due-diligence-in-europe/ (accessed 5 August 2021), for an overview and links towards the instruments cited.
} 
already outdated. Even if the details of the upcoming due diligence regulation in the EU are not yet clear, it is to be expected that they will not only apply to companies registered in the EU, but also to those governed by the law of a third country, such as Switzerland, when they operate in the internal market. ${ }^{28}$

The new due diligence legislation also does not comply with international due diligence standards, such as the UN Guiding Principles on Business and Human Rights (UNGPs) or the OECD Guidelines for Multinational Enterprises. This is the case for the 'low-risk approach' which automatically exempts companies for child labour due diligence based on a country's classification in the UNICEF Children's Rights in the Workplace Index. Completely exempting SMEs from child labour due diligence even for the worst forms of child labour is simply not arguable in light of the UNGPs, the OECD Due Diligence Framework or the relevant ILO standards. While it is undisputed that conducting due diligence is challenging for SMEs and that clear manageable requirements as well as targeted support are important, the proposed exception will probably not work in their favour. Many SMEs will be faced with due diligence requirements upstream, by the companies that they supply to and that are subject to the new law.

Finally, the lack of an enforcement mechanism raises the question of its practical utility. Recently adopted human rights due diligence legislation, whether in France, Germany, Norway or in discussions about the EU corporate due diligence directive, all contain public enforcement mechanisms and/or civil liability provisions. Not surprisingly, reactions to the Swiss Human Rights Due Diligence legislation and the Ordinance on Child Labour and Conflict Minerals have so far been mixed.

\section{Conclusion}

The new Swiss due diligence legislation was adopted after the rejection of the Swiss Responsible Business Initiative that aimed to include in the Swiss Constitution a general human rights due diligence obligation with a corporate liability provision. It covers only some aspects of child labour and conflict minerals due diligence and does not introduce new legal liabilities. The experience of the political process in Switzerland highlighted many challenges related to the introduction of mandatory due diligence and may offer some lessons for other countries considering similar steps. First, the strong push and the power of civil society remained under-estimated both by the government and the legislator. This led to a rather hasty drafting process, which ultimately did not benefit the result. This relates to a second challenge: aligning domestic legislation with international standards, particularly the UNGPs and the OECD Guidelines, goes beyond including some of the key language and terms but requires thorough analysis of domestic law, particularly with regard to concepts like corporate liability and burden of proof to ensure coherence. The third challenge, which goes back to the first finding, is that introducing mandatory due diligence is a process. In order to ensure legitimacy and

28 Resolution of the European Parliament suggesting a Directive on Corporate Due Diligence and Corporate Accountability 2021, art 2, para 3. 
credibility towards civil society and business, it is critical to define a clear roadmap and criteria in order to recalibrate the system and adjust regulations if needed. As the ecosystem of corporate responsibility in which all companies are operating is developing quickly, navigating it safely in the interest of rights-holders requires not only monitoring corporate behaviour but also ensuring that mandatory due diligence requirements can live up to the expectations and deliver on the ground. 